\title{
Financial and Real Integration
}

\author{
Scott L. Baier \\ Clemson University \\ Federal Reserve Bank of Atlanta \\ Gerald P. Dwyer, Jr. \\ Federal Reserve Bank of Atlanta \\ University of Carlos III, Madrid
}

November 2007

\begin{abstract}
We examine the relationship between real and financial integration. Real integration is measured by productivities of capital and labor from trade data for 1982 to 1997. Financial integration is measured by the black market exchange rate. We find more evidence of convergence to equality for returns to capital than for returns to labor. There is some support for convergence of black market premia being associated with declines in black market premia.

Acknowledgement 1 We thank the Associazione Guido Carli and Fondazione Cesifin Alberto Predieri for supporting the Fifth Colloquium at which this paper was presented and at which we received many helpful comments. Helpful comments also were received from participants at the INFINITI conference at Trinity College, Dublin when we presented the paper there. We thank the Federal Reserve Bank of Atlanta for research support and Linda Mundy for editorial
\end{abstract}


assistance. Baier appreciates financial support from the National Science Foundation for related research. The views expressed here are the authors' and not necessarily those of the Federal Reserve Bank of Atlanta or the Federal Reserve System. Any remaining errors are the authors' responsibility.

In this paper, we use the relative factor content of international trade to estimate the productivities of capital and labor and examine how changes in them from 1982 to 1997 are related to financial integration. There is little information available on factor returns that is comparable across countries but available data on factor returns are correlated with these productivities of labor and capital computed from trade data. ${ }^{1}$

We start with a standard international-trade model: the Heckscher-Ohlin-Vanek (HOV) model. In this standard model of an integrated world in which all countries produce all goods, trade in factor services is a function of a country's endowments relative to its consumption of factor services, and trade in goods is a substitute for direct trade in factor services and for migration of factors. With identical technologies, the HOV model implies that 1 . A country has a comparative advantage in producing goods that use its relatively more abundant factors, 2. A country is a net exporter of its relatively abundant factors' services and 3. Factor returns are equalized across countries. $^{2}$

Empirical tests of the HOV model examine the relationship between endowments and the observed pattern of trade and find that the HOV model explains little of the direction or magnitude of trade. ${ }^{3}$ In addition, violations of absolute factor price equalization are virtually self-evident in the data on measured wages across countries.

\footnotetext{
${ }^{1}$ Baier, Dwyer and Tamura (2007) provide references.

${ }^{2}$ At the level of aggregation used for the countries in this paper, there are no industries with zero production. This suggests to us that the conditions for factor price equalization are likely not to be wildly unrealistic in the context of the differences across countries envisaged in the theory.

${ }^{3}$ A partial list of these studies include Maskus (1985) Bowen, Leamer, and Sveikauskus (1985), Trefler (1993, 1995) and Davis and Weinstein (2001).
} 
Hence, there must be explanations of the factor content of trade besides the simple HOV model.

Half a century ago, Leontief (1953) suggested a possible explanation for the HOV model's poor performance - some countries may use factors of production more efficiently than others. An innovative series of papers by Bowen, Leamer and Sveikauskas (1987) and Trefler $(1993,1995)$ followed Leontief's suggestion and introduced technological differences into the HOV model. Trefler (1993) shows that factor-augmenting technology can equate actual trade in factor services and the theoretically implied trade in factor services. Allowing for factor-augmenting technological differences implies that factor prices are equalized in terms of relative efficiency units. For example, if labor-augmenting technology is five times higher in the United States than in Mexico, workers in the U.S. will receive a wage that is five times greater than the wage paid to workers who are in Mexico and otherwise identical. Trefler presents evidence that there is a strong relationship between relative factor payments and relative factoraugmenting productivity.

In an earlier paper, Robert Tamura and we (Baier, Dwyer and Tamura 2007) also show that these measures of factor-augmenting technology obtained from trade theory are related to total factor productivity. Theoretically, factor productivity implied by trade is similar to total factor productivity in the following sense: If factor productivity indicates that a unit of capital in the United States is twice as productive as a unit of capital in the Philippines, then the return to capital will be twice as high in the U.S. as in the Philippines. Similarly, for a given level of capital in the U.S. and the Philippines, if total factor productivity in the U.S. is twice as high as total factor productivity in the Philippines, then capital and labor's returns can be twice as high in the U.S. Therefore, total factor productivity has the same effect on the returns to capital and labor as factor productivity from the HOV model.

In that earlier paper, we examined the determinants of factor productivity across 
countries. We found that protection of private property rights is the single most important explanation of cross-country differences in factor productivity in 1997. Democracy has little relationship with trade productivities once property rights are included in the analysis. Measures of geography other than distance to a large market are not important.

In this paper, we examine changes in the productivity of capital and labor over time and how they are related to a particular measure of financial integration.

We find that capital productivities around the world are more similar than labor productivities in 1982 and also show much more evidence of converging from 1982 to 1997. Measuring financial integration for a set of countries that includes many different levels of development of financial markets is difficult. We suggest black market exchange rates as a measure of financial integration. Overall, black market exchange rates deviate less from official exchange rates by 1995 than they did in 1980 . We find some evidence that this convergence of black market exchange rates to official rates has been associated with convergence of capital productivities.

In the next section, we summarize how the productivities of labor and capital are computed. We then summarize the data on black market exchange rates and examine the data for an association of changes in black market exchange rates and capital and labor productivities.

\section{PRODUCTIVITIES OF LABOR AND CAPITAL}

The productivities of labor and capital are those implied by international trade in goods given assumptions about technology and consumption of goods across countries. 


\section{HOV Theory and Productivity Differences}

The details of the computation of labor and capital productivities are available elsewhere (Trefler 1993; Baier, Dwyer and Tamura 2007.) In this section, we outline how the productivities are computed.

The Heckscher-Ohlin-Vanek theory of trade can be used to generate measures of productivity based on a comparison of the measured factor content of trade and a predicted factor content of trade. The basic analytical construct is a transformation of trade in goods into implicit trade of the factor services used to produce the goods. The computations assume that countries have identical constant returns to scale production functions, markets are perfectly competitive, and the world is free from barriers that distort trade. This means that the measures of productivity reflect tariff and non-tariff barriers or inducements to trade. To rule out corner solutions in which there is no trade in some goods, the analysis assumes that endowments of factors across countries are distributed in such a way that there is an integrated world equilibrium with all countries producing some of all goods. The analysis proceeds by comparing the measured factor content of trade and a predicted factor content given the endowment of factor services in a country.

The measured factor content of trade is determined from actual trade in goods at a detailed level. A presumed common technology of an input-output matrix of coefficients for the United States is used to determine this measured factor content of trade.

The predicted factor content of trade is a function of factor availability, production and domestic consumption. In the baseline HOV model, there are no differences in how efficiently factors are used across countries and resources are fully employed. If people in all countries have identical and homothetic preferences, country $i$ 's expenditure is proportional to its share of world expenditure. The predicted factor content of 
trade is factor use in domestic production minus factor use in domestic consumption.

The measured factor content of trade need not equal the predicted factor content of trade. These differences are the basis of the numerous tests of whether the HOV model characterizes actual trade.

An alternative way of posing the issue is to ask what differences in technology or productivity are necessary for the measured and predicted factor content of trade to be the same, an innovation due to Trefler (1993.) The measured factor content of trade is the same as the measured content of trade based on the common technology above. Suppose that technology differences are factor augmenting and the same across industries in a country. Then the predicted factor content of trade by a country adjusted for differences in productivity involves the unknown productivities for each factor for each country. Equating the measured and predicted factor contents of trade provides a productivity matrix for all countries for all factors.

A normalization is necessary because the productivities can be determined independently for all but one country. ${ }^{4}$ It is standard to normalize the productivities to one for the United States, which is natural given that the "common technology" is measured from United States input-output tables. Measuring the productivities by the average for all the countries is one obvious alternative normalization. For our purposes of measuring productivities over time, it is more informative to measure the productivities relative to the average for all countries rather than relative to the U.S. If measured relative to the U.S., then productivity change in a country is measured relative to productivity change in the U.S. If measured relative to the average, then productivity change in a country is measured relative to productivity change in the average country.

\footnotetext{
${ }^{4}$ While not obvious from this development, the estimates of productivity for a factor are independent of mismeasurement of the quantities of other factors and their productivities.
} 


\section{Data}

As is standard in most empirical trade research, the data used in this study are drawn from a variety of sources. All data are for 79 countries in each year based on up to 32 industries of traded goods. The data on trade flows are from Feenstra (2000.)

For inputs, we use data for the capital stock and the labor force measured in effective labor units. The capital stock measures are constructed using the perpetual inventory method with an annual depreciation rate of 13.3 percent, as in Leamer (1984), using real investment data from Baier, Dwyer, and Tamura (2006). Aggregate labor force is converted into effective labor force units by multiplying the labor force by $\exp \left(\varphi\left(e d u c_{i}\right.\right.$, exper $\left.\left._{i}\right)\right)$ where $e d u c_{i}$ is the number of years of schooling for the average worker in country $i$, exper $_{i}$ is the average level of experience in country $i$ and $\exp \left(\varphi\left(e d u c_{i}\right.\right.$, exper $\left.\left._{i}\right)\right)$ reflects returns to education and experience. ${ }^{5}$ Data on the labor force are from the World Bank (2002) and data for the conversion to effective labor are from Baier, Dwyer, and Tamura (2006).

Our construction of the direct and indirect input requirement of factors to produce goods is standard (Bowen, Leamer and Sveikauskas 1987). Input requirements are based on the 1982, 1987, 1992 and 1997 input-output tables for the United States. The stocks of capital by industry in the U.S. are from the U.S. series "fixed reproducible tangible wealth." To equate the total of these capital stocks and our computed U.S. perpetual-inventory aggregate capital stock, the capital stock in each industry is

\footnotetext{
${ }^{5}$ The derivatives of $\varphi\left(\operatorname{educ}_{i}\right.$, exper $\left._{i}\right)$ are the returns to an additional year of schooling or experience that can be estimated from Mincerian wage regressions. As in Hall and Jones (1999), Debaere and Demiroglu (2003) and Baier, Dwyer and Tamura (2006), we assume that the return to education for the first four years of schooling is 13.4 percent, 10.1 percent for the second four years and 6.8 percent for all years of education above the 8th year. As in Bils and Klenow (2000), we assume the return to experience is quadratic.
} 
multiplied by the ratio of the U.S. perpetual-inventory aggregate capital stock to the total of the U.S. capital stocks from fixed reproducible tangible wealth. This results in a sum of the capital stocks by industry in the U.S. equal to our estimate of the aggregate U.S. capital stock. Data for the U.S. labor force employed in each sector are from the National Income and Product Accounts of the United States and the Bartelsman, Becker, and Gray (2002) productivity database for 1982, 1987, 1992 and 1997. The total labor force is adjusted to equal the World Bank's estimate of the U.S. labor force (World Bank 2002). Data on workers' average education by industry for the U.S. are from the 1990 Census (Ruggles, Sobek et al. 2003). Income per capita and population are from the World Bank (2002).

Each country's share of world consumption is its share of absorption of goods and services in all countries.

\section{CAPITAL AND LABOR PRODUCTIVITIES}

\section{Estimated Productivities}

Table 1 shows the list of countries for which we have computed productivities. The countries are from quite different parts of the world, with quite different levels of incomes and associated development.

Figure 1 shows the labor and capital productivities for each of the countries for 1982, 1987, 1992 and 1997. All of these productivities are normalized so that the average productivity of labor and the average productivity of capital are unity in each year.

It is apparent from Figure 1 that there is a substantial amount of variation that at first glance has little to do with the productivity of labor and capital as commonly understood. For example, Madagascar - MDG in the graphs - has the highest capital

productivity in the world in 1982, 1987 and 1992 and one of the highest in the world in 
1997. Why? With the exception of being an importer of crude oil and an exporter of petroleum products, Madagascar primarily exports agricultural products and imports goods for use on the islands. Switzerland (CHE in the figures) has the highest labor productivity in the world. These figures are not obviously implausible. It is arguable that, at least in some cases, the productivities are distorted by resources such as oil deposits that are not included in the calculations.

Table 2 provides summary statistics on the productivities. The standard deviation of the productivity of labor increases from 1982 to 1987 and then changes little by 1997. The range increases with the lower end of the range lower in 1997 than in 1982 and the upper end of the range virtually the same in 1982 and 1997. In some ways, this is surprising given the emphasis on globalization. The standard deviation of the productivity of capital, though, declines from 1982 to 1997. The range of the productivities of capital declines due to a decrease in the maximum. Probably the standard deviations are a better indicator of the changes in the distribution than the ranges, which can be affected by idiosyncratic variation in individual countries, but there is little evidence of convergence of the labor productivities.

It might seem that the apparent convergence of capital productivity could be a reflection of the decline in the calculated productivity of capital in Madagascar. Such is not the case. The standard deviations of capital productivity without Madagascar for each year are 1982, 0.809; 1987, 0.788; 1992, 0.492; and 1997, 0.523. While not as large as the decline in Table 2, the decrease in the standard deviation still is substantial. ${ }^{6}$

\footnotetext{
${ }^{6}$ Steven Ongena suggested treating some additional high capital productivity countries as outliers. We deleted high initial capital productivity countries in addition to Madagascar, namely Trinidad and Tobago, Sierra Leone and the Democratic Republic of the Congo. With these additional observations deleted, the standard deviation of capital productivities decreases uniformly from 0.667 to 0.448 . The estimated coefficients of autoregressions similar to those in Table 3 show less mean reversion for capital productivity, which is to be expected. (The autoregressive coefficient is 0.87 ).
} 
The median labor productivity has declined, which means that labor productivity in the typical country has not increased as rapidly as it has in these countries on average. At the same time, the median capital productivity has increased, approaching one by 1997. This is an interesting difference.

The correlations of labor and capital productivities increase consistently from the low value of 0.04 in 1982 to the highest value of 0.39 in 1997.

Figures 2 and 3 provide a different perspective on the distributions of capital and labor productivities.

The distributions of labor productivity and capital productivity are quite different. The labor productivities are skewed, with more countries below the average than above it. This figure provides some perspective on the reason for the different behavior of the medians of the distributions of labor and capital productivity. Median labor productivity actually fell from 0.62 in 1982 to $0.48,0.49$ and 0.50 in 1987, 1992 and 1997. At the same time, median capital productivity rose from 0.72 and 0.70 in 1982 and 1987 to 0.89 and 0.97 in 1992 and 1997. The arithmetic averages, of course, are one throughout.

Standard convergence regressions also lead to the conclusion that capital productivity has converged and labor productivity has not. Table 3 presents a variant of standard unconditional-convergence regressions, which basically are unit-root tests. The regressions are run for 1997 as the final year and 1982 as the initial year. It is most informative to present the regressions in levels with the t-ratio for the DickeyFuller test and we do that in the table. The autoregressive coefficients themselves Interestingly, the constant term in the regression for labor productivity is small relative to its mean with these four countries deleted.

The more general issue of the effects of natural resources and specialized production arrangements on these estimated productivities is an interesting question that we are examining in our continuing research. 
highlight the difference. The coefficient for labor in 1982 is very close to one. The coefficient for capital in 1982 is well below one. ${ }^{7}$ The constant term in the labor regression suggests that there is a very large downward trend in labor productivity, which is dubious at best given Figure 2. ${ }^{8}$ There definitely is a downward moment of the relatively low labor productivities, but this cannot translate into a downward trend because the productivities have a lower bound of zero.

There are, of course, lots of reasons to be dubious about these regressions for generating conclusions. ${ }^{9}$ Nonetheless, the results are striking in terms of the question under consideration. A natural result of integration of economies is convergence of returns to factors of production. Has there been integration in the sense that capital productivities have become more similar? The answer fairly clearly is "yes". Has there been integration in terms of labor productivities? Not obviously!

In one sense, this result is not surprising. Financial markets have become more integrated and this can have a fairly direct effect of raising low returns to capital in some countries by supporting an outflow and lowering high returns in other countries by supporting an inflow.

In another sense, this result is surprising if taken at face value. If the marginal product of capital increases because of inflows of capital, this increases the demand for labor and the marginal product of labor should increase unless the elasticity of supply of labor is infinite.

Are capital and labor productivities this disconnected? A little bit of evidence says not. The correlations of changes in labor and capital productivities are indeed positive. The correlation of changes in labor productivity and capital productivity is

\footnotetext{
${ }^{7}$ Regressions for the logarithms of the productivities lead to the same conclusion concerning convergence of productivities.

${ }^{8}$ We thank Jouko Vilmunen for pointing this out to us.

${ }^{9}$ Not the least of these reasons are shortcomings in this context of classical statistical analysis compared to a Bayesian approach along the lines of Dwyer et al (2007).
} 
0.38 from 1982 to 1997 . While hardly overwhelming, this correlation is not zero. ${ }^{10}$ The correlation of changes in the logarithms of the productivities is quite a bit higher, 0.80 , suggesting that there is quite a bit of force to this argument, the seeming disconnect between the changes in the distributions of the productivities aside.

Figure 4 illustrates the issue in a different way. Figure 4 shows the growth rate of labor and capital productivity in each country for 1982 to 1997. Many countries had rising labor and capital productivity. More than a few countries had falling labor and capital productivity. It is worthwhile recalling that the productivities are measured relative to the average in each year, so falling productivity does not mean that returns to labor and capital falls. Falling productivity in Figure 4 means that returns to labor and capital fell relative to the average. While not as bad as falling absolutely, falling behind hardly is attractive. More than a few countries also had falling labor productivity and rising capital productivity. Only two, Cyprus and Singapore, had rising labor productivity and falling capital productivity.

Perhaps a measure of financial market integration will be informative about the integration of capital markets, and possibly labor markets as well.

\section{FINANCIAL INTEGRATION}

With such a disparate set of countries, it is not immediately obvious how to measure financial integration.

The best measure would be the set of prices of various risk factors in foreign markets. This has a solid theoretical basis and an unambiguous interpretation. Such measures based on markets for stocks and bonds are not likely to be very useful for our set of countries though. A country such as Vietnam for example is unlikely to have representative data from financial markets to permit reliable and comparable

\footnotetext{
${ }^{10}$ The $\mathrm{p}$-value for a test that the correlation is zero is 0.06 percent, far less than usual statistical significance levels.
} 
estimation of the prices of risk factors. The same statement can be made for many other countries in our set of data.

An alternative measure is the openness of domestic financial markets to foreigners. This is the path followed by Edison and Warnock (2003). Examination of their data reveals though, that even this measure is not available for many markets, no doubt because some of our countries do not have organized exchanges with data available. Instead of going down this road, we examine the foreign exchange market as a plausible candidate for informative data.

We suggest that the black market premium is likely to be a useful measure of financial integration. A black market is prima facie evidence of an imperfectly functioning market for foreign exchange. In addition, a black market for foreign exchange implicitly indicates that some transactions occur at more favorable exchange rates, which is itself an indication of likely favoritism in the allocation of preferential exchange rates and corruption in at least some cases. Finally, a black market in foreign exchange is likely to be associated with other policies that hinder the efficient operation of a country's economy and would be reflected in low productivities of labor and capital.

\section{Data on Black Market Exchange Rate}

The data on the black market exchange rate are from a compilation of black market premia by Gwartney and Lawson (2005). These data primarily are from various issues of the MRI Bankers' Guide to Foreign Currency. In this source, the black market exchange rates are estimates for the parallel domestic market for foreign exchange (Monetary Research Institute, 2005). Gwartney and Lawson (2005, p. 177) supplement these data by data from other sources when necessary. 


\section{Preliminary Analysis of the Data}

Figure 5 shows the black market premia for 1980 and 1995 . These dates are two years before the first and two years before the last measures of capital and labor productivities. To facilitate later analysis, the figures show gross premia in percent, which means that the "premium" is the black market exchange rate relative to the official exchange rate in percent. As a result, a gross premium of 100 percent means that the "black market exchange rate" is the same as the official exchange rate.

It is immediately obvious in Figure 4 that the frequency of black market exchange rates well above the official rate has decreased markedly over the fifteen years covered by the figure. Many countries had substantial black market premia in 1980 and not many had much in the way of black market premia by 1995. This strikes us as prima facie evidence of greater effective financial integration among economies.

Figure 6 shows the distribution of the black market premia in 1980, 1985, 1990 and 1995. It is clear that there is substantial movement toward black market gross premia close to 100 percent.

In one sense, the histograms are less revealing than they could be. Even in 1995, there are quite a few countries that have gross premia above 100, in fact 41 countries. Table 4 presents summary statistics on the black market premia for 1980, 1985, 1990 and 1995.

\section{FINANCIAL AND REAL INTEGRATION}

Figure 7 shows the relationship between changes in the black market premium from 1980 to 1995 and capital productivity from 1982 and 1997. The figure shows relative capital productivities and the relative black market premium. An increase in capital productivity is an increase in capital productivity relative to the average for the world. The gross black market premia are never less than 100 percent, so a 
decrease in the relative black market premium is a decrease toward one hundred in all cases and an improvement in integration. The horizontal and vertical reference lines divide the figure into four quadrants. The upper left quadrant represents an improvement in capital productivity and the black market premium, the upper right quadrant represents an improvement in capital productivity and a worsening of the black market premium, the lower left quadrant represents a worsening of capital productivity and an improvement in the black market premium and the lower right quadrant represents a worsening of capital productivity and a worsening of the black market premium.

Few countries have higher black market premia in 1995 than in 1980. In fact only Haiti, Venezuela and Nigeria have black market premia that increased substantially over those years. Each of these countries has a lower relative capital productivity in 1995 than in 1980.

It is clear that a fall in the black market premium is not a guarantee of an improvement in relative capital productivity. Countries with improvements in their black market premia have increases and decreases in relative capital productivity. Relatively few countries have higher black market premia in 1995 than in 1982, but all of the countries with large increases in black market premia have lower relative capital productivity in 1997 than in 1982. No country with a higher black market premium in 1995 has a higher relative capital productivity in 1997.

Figure 8 shows a similar graph for labor productivity. Venezuela and Nigeria also have lower labor productivity, although Haiti has higher labor productivity.

Does this pattern hold for subperiods?

Figure 9 shows the changes in capital productivities and black market premia for the three subperiods. There are a few exceptions, but it still is true that increases in capital productivity are seldom associated with increases in the black market premium. 
Figure 10 shows a similar result for labor productivity.

Table 5 presents the results of Chi-square tests of association between changes in black market premia and changes in labor and capital productivities. The changes in black market premia are divided into three classes: falling, unchanging and increasing. No change is quite likely since some countries never have any deviation from official exchange rates. ${ }^{11}$ The changes in productivities are divided into two classes: rising and falling. Because it is a test of association, these test results do not impose any constraints such as linearity. We interpret the p-values in Table 4 as providing some support for the importance of black market premia for productivity.

\section{CONCLUSION}

Some results seem clear, even though more definitive conclusions await further research.

Capital productivities around the world have tended to converge more than labor productivities from 1982 to 1997. This is so even though capital productivities were more similar than labor productivities in 1982.

Financial integration is a possible explanation for the convergence of capital productivities. Measuring financial integration for a set of countries that includes many different levels of development of financial markets is difficult. We suggest black market exchange rates as a measure of financial integration. Black market exchange rates deviate less from official exchange rates by 1995 than they did in 1980 . We find some evidence that this convergence of black market exchange rates has been associated with convergence of capital productivities.

\footnotetext{
${ }^{11}$ The fraction of countries with no change in the black market premium is 20 percent from 1980 to 1985,25 percent from 1985 to 1990 and 38 percent from 1990 to 1995.
} 


\section{REFERENCES}

Baier, Scott L., Gerald P. Dwyer, Jr. and Robert Tamura. 2006. "How Important Are Capital and Total Factor Productivity for Economic Growth?" Economic Inquiry 44 (January), pp. 23-49.

Baier, Scott L., Gerald P. Dwyer, Jr. and Robert Tamura. 2007. "Factor Returns, Institutions, and Geography: A View From Trade." Unpublished paper, Federal Reserve Bank of Atlanta.

Barro, Robert J. 1996. "Democracy and Growth." Journal of Economic Growth 1 (March), pp.1-27.

Bartelsman, Eric J., Randy A. Becker and Wayne B. Gray. 2002. "The Manufacturing Industry Productivity Database." National Bureau of Economic Research Technical Working Paper 205.

Bils, Mark, and Peter J. Klenow. 2000. "Does Schooling Cause Growth?" American Economic Review 90 (December), pp. 1160-83.

Bowen, Harry P., Edward E. Leamer and Leo Sveikauskas. 1987. "Multicountry, Multifactor Tests of the Factor Abundance Theory. American Economic Review 77 (December), pp. 791-809.

Debaere, Peter and Ukuf Demiroglu. 2003. "On the Similarity of Country Endowments." Journal of International Economics. 59 (January), pp.101-36.

Dwyer, Jr., Gerald P., Mark Fisher, Thomas Flavin and James R. Lothian. 2007. "Purchasing Power Parity and the Euro." Unpublished paper.

Encylopedia Britannica. 2005. 
Feenstra, Robert. 2000. "World Trade Flows: 1980-1997." University of California at Davis, manuscript and CD.

Grosse, Robert E., with Clarice Pechman. 1994. Foreign Exchange Black Markets in Latin America. Westport, Connecticut: Praeger.

Gwartney, James and Robert Lawson with Erik Gartzke. 2005 Economic Freedom of the World: 2005 Annual Report. Vancouver, Canada: Fraser Institute.

Hall, Robert E., and Charles I. Jones. 1999. "Why Do Some Countries Produce So Much More Output Per Worker Than Others?" The Quarterly Journal of Economics. 114 (February), pp. 83-116.

Leamer, Edward E. 1984. Sources of International Comparative Advantage: Theory and Evidence. Cambridge, Massachusetts: MIT Press.

Leontief, Wassily W. 1953. "Domestic Production and Foreign Trade: The American Capital Position Reexamined." Proceedings of the American Philosophical Society 97 (4), pp. 332-49.

Monetary Research Institute. 2005. MRI Bankers' Guide to Foreign Currency, 200506. 57th Edition. Houston: Monetary Research Institute.

Ruggles, Stephen, Matthew Sobek et al. 2003. Version 3. Minneapolis: Historical Census Project, University of Minnesota.

Trefler, Daniel. 1995. "The Case of Missing Trade and Other Mysteries." American Economic Review 85 (December), pp. 1029-46.

Trefler, Daniel. 1993. "International Factor Price Differences: Leontief was Right!" Journal of Political Economy 101 (December), pp. 961-87. 
World Bank. 2002. World Development Indicators 2002. Washington, D.C.: The World Bank. 
Table 1

Countries in This Dataset

\begin{tabular}{|c|c|}
\hline Algeria & Kenya \\
\hline Argentina & Korea \\
\hline Australia & Madagascar \\
\hline Austria & Malawi \\
\hline Bangladesh & Malaysia \\
\hline Bolivia & Mauritius \\
\hline Brazil & Mexico \\
\hline Bulgaria & Morocco \\
\hline Cameroon & Netherlands \\
\hline Canada & New Zealand \\
\hline Chile & Niger \\
\hline Colombia & Nigeria \\
\hline Congo Democratic Republic of & Norway \\
\hline Congo Republic of & Pakistan \\
\hline Costa Rica & Panama \\
\hline Cyprus & Paraguay \\
\hline Denmark & Peru \\
\hline Dominican Republic & Philippines \\
\hline Ecuador & Portugal \\
\hline Egypt & Romania \\
\hline El Salvador & Senegal \\
\hline Finland & Sierra Leone \\
\hline France & Singapore \\
\hline Gabon & South Africa \\
\hline Germany & Spain \\
\hline Ghana & Sri Lanka \\
\hline Guatemala & Sweden \\
\hline Guyana & Switzerland \\
\hline Haiti & Taiwan \\
\hline Honduras & Thailand \\
\hline Hong Kong & Trinidad and Tobago \\
\hline Hungary & Tunisia \\
\hline India & Turkey \\
\hline Indonesia & Uganda \\
\hline Ireland & United Kingdom \\
\hline Israel & United States \\
\hline Italy & Uruguay \\
\hline Jamaica & Venezuela \\
\hline \multirow[t]{2}{*}{ Japan } & Zambia \\
\hline & Zimbabwe \\
\hline
\end{tabular}


Table 2

Summary Statistics on the Estimated Labor and Capital Productivities

\begin{tabular}{|c|c|c|c|c|c|}
\hline & Mean & Median & $\begin{array}{c}\text { Minimum } \\
\text { Value }\end{array}$ & $\begin{array}{c}\text { Maximum } \\
\text { Value }\end{array}$ & $\begin{array}{c}\text { Standard } \\
\text { Deviation } \\
\end{array}$ \\
\hline 1982 Labor Productivity & 1.0 & 0.619 & 0.069 & 3.751 & 0.902 \\
\hline 1987 Labor Productivity & 1.0 & 0.484 & 0.040 & 4.908 & 1.082 \\
\hline 1992 Labor Productivity & 1.0 & 0.495 & 0.042 & 4.327 & 1.090 \\
\hline 1997 Labor Productivity & 1.0 & 0.499 & 0.029 & 3.755 & 1.049 \\
\hline 1982 Capital Productivity & 1.0 & 0.717 & 0.235 & 8.132 & 1.143 \\
\hline 1987 Capital Productivity & 1.0 & 0.696 & 0.102 & 6.296 & 0.988 \\
\hline 1992 Capital Productivity & 1.0 & 0.891 & 0.126 & 5.809 & 0.734 \\
\hline 1997 Capital Productivity & 1.0 & 0.971 & 0.112 & 3.391 & 0.540 \\
\hline
\end{tabular}

Correlations of Productivities

$\begin{array}{lr}1982 & .038 \\ 1987 & .098 \\ 1992 & .304 \\ 1997 & .393\end{array}$

There are 79 countries for each of the years. By construction, the mean labor productivity and mean capital productivity for each year are one. 
Table 3

Convergence of Productivities to Means

1982 to 1997

\begin{tabular}{|c|c|c|c|c|c|}
\hline Dependent Variable & Constant & $\begin{array}{c}\text { Coefficient } \\
1982 \\
\text { Productivity }\end{array}$ & $\begin{array}{l}\text { t-ratio } \\
\text { for change }\end{array}$ & $\mathrm{R}^{2}$ & $\mathrm{~S}_{\mathrm{e}}$ \\
\hline \multirow[t]{2}{*}{1997 Labor Productivity } & -8.011 & 1.011 & 0.017 & .753 & .521 \\
\hline & $(.088)$ & $(.065)$ & & & \\
\hline \multirow[t]{2}{*}{1997 Capital Productivity } & 0.731 & 0.269 & -16.538 & .324 & .447 \\
\hline & $(.067)$ & $(.044)$ & & & \\
\hline
\end{tabular}

The t-ratios of parameters are in parentheses. 
Table 4

Summary Statistics on Black Market Exchange Rates 1980 to 1995

All Black Market Exchange Rates

\begin{tabular}{|c|c|c|c|c|c|c|}
\hline Year & & Mean & Median & Maximum & Minimum & $\begin{array}{c}\text { Standard } \\
\text { Deviation } \\
\end{array}$ \\
\hline 1980 & & 145.9 & 106 & 728 & 100 & 99.5 \\
\hline 1985 & & 165.8 & 107 & 1346 & 100 & 175.9 \\
\hline 1990 & & 124.3 & 104 & 516 & 100 & 61.5 \\
\hline 1995 & & 109.1 & 101 & 386 & 100 & 39.4 \\
\hline 1997 & & 109.5 & 101 & 371 & 100 & 34.5 \\
\hline \multicolumn{7}{|c|}{ Black Market Exchange Rates Not Equal to Official Exchange Rate } \\
\hline Year & $\begin{array}{c}\text { Number of } \\
\text { Observations }\end{array}$ & Mean & Median & Maximum & Minimum & $\begin{array}{c}\text { Standard } \\
\text { Deviation }\end{array}$ \\
\hline 1980 & 61 & 159.4 & 116 & 728 & 101 & 109.8 \\
\hline 1985 & 61 & 185.2 & 119 & 1346 & 101 & 196.3 \\
\hline 1990 & 47 & 140.9 & 113 & 516 & 101 & 75.6 \\
\hline 1995 & 41 & 117.5 & 103 & 386 & 101 & 53.6 \\
\hline 1997 & 48 & 115.6 & 104 & 371 & 101 & 43.3 \\
\hline
\end{tabular}


Table 5

Tests for Association Between Productivities and Black Market Exchange Rates 1982 to 1997

\begin{tabular}{llll}
\hline \multicolumn{1}{c}{ Changes } & & Chi-square & Chi-square p-value \\
\hline Productivity & $\begin{array}{c}\text { Black Market } \\
\text { Exchange Rate }\end{array}$ & & \\
\hline 1992 to 1997 Labor Productivity & 1980 to 1985 & 3.779 & .151 \\
1992 to 1997 Labor Productivity & 1985 to 1990 & 3.847 \\
1992 to 1997 Labor Productivity & 1990 to 1995 & & .016 \\
& & 3.785 & .146 \\
1982 to 1987 Capital Productivity & 1980 to 1985 & 9.944 \\
1987 to 1992 Capital Productivity & 1985 to 1990 & .007 \\
1992 to 1997 Capital Productivity & 1990 to 1995 & .054 \\
\hline
\end{tabular}




\section{Figure 1}

Productivities of Capital and Labor
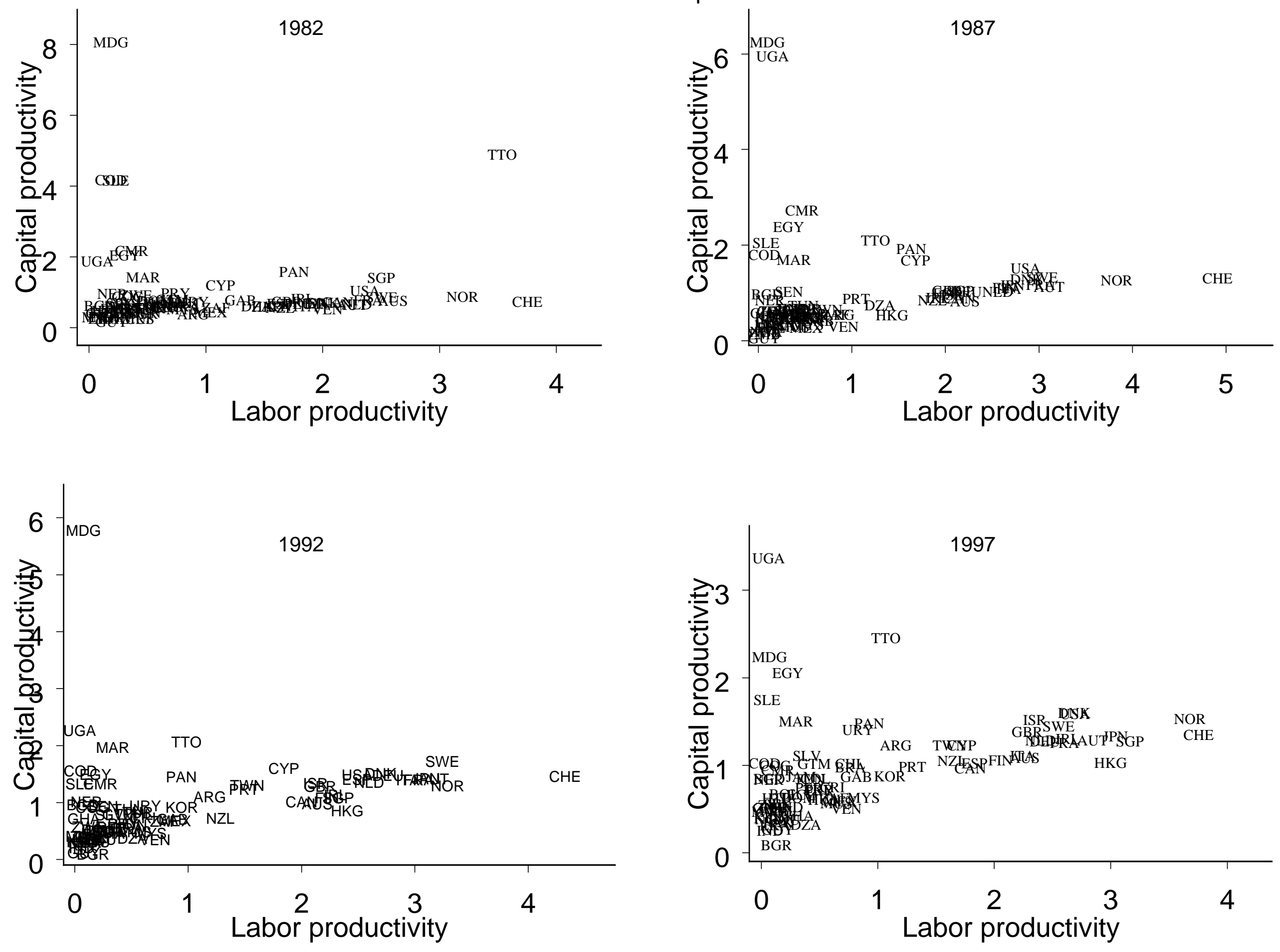
Figure 2

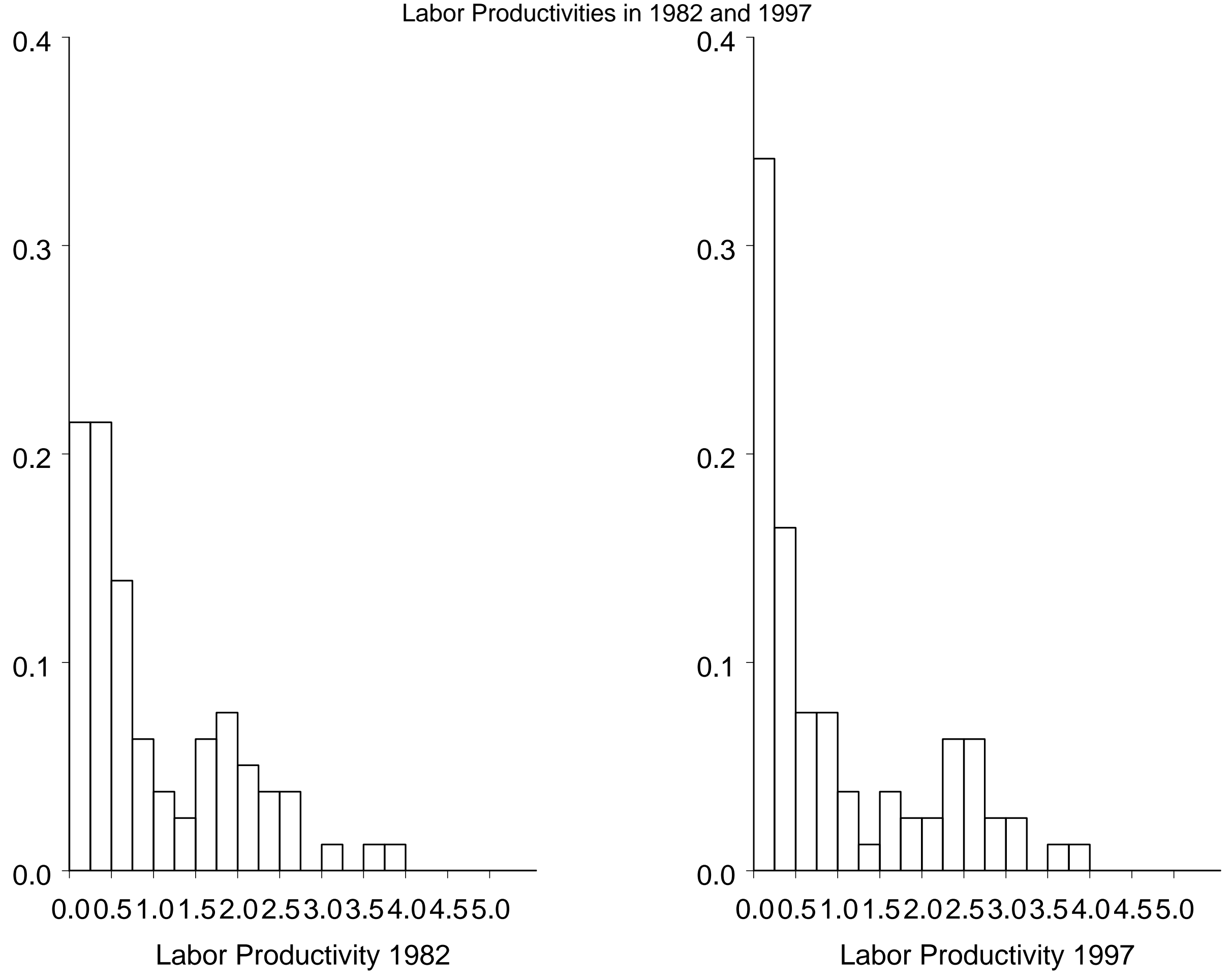


Figure 3

Capital Productivities in 1982 and 1997
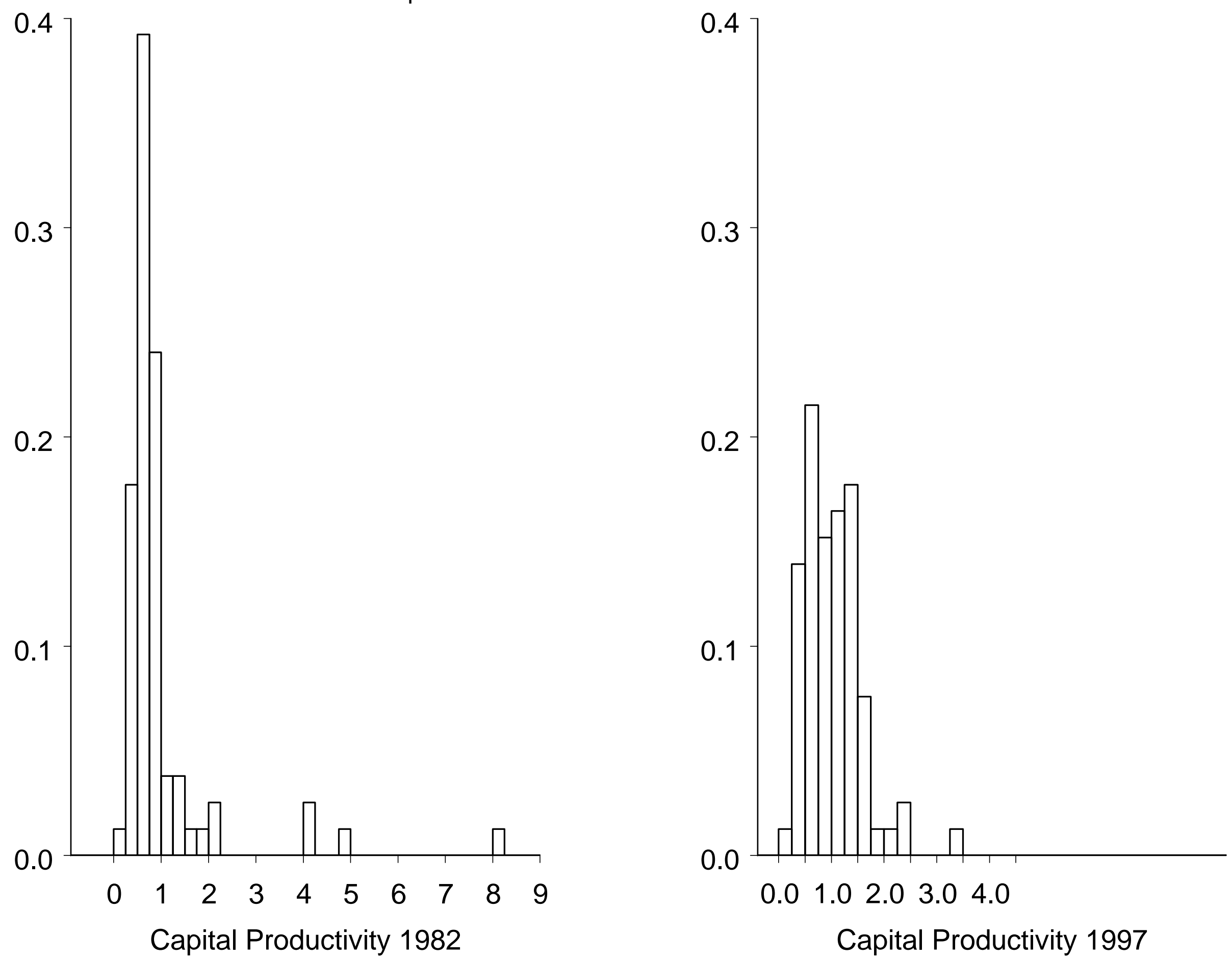
Figure 4

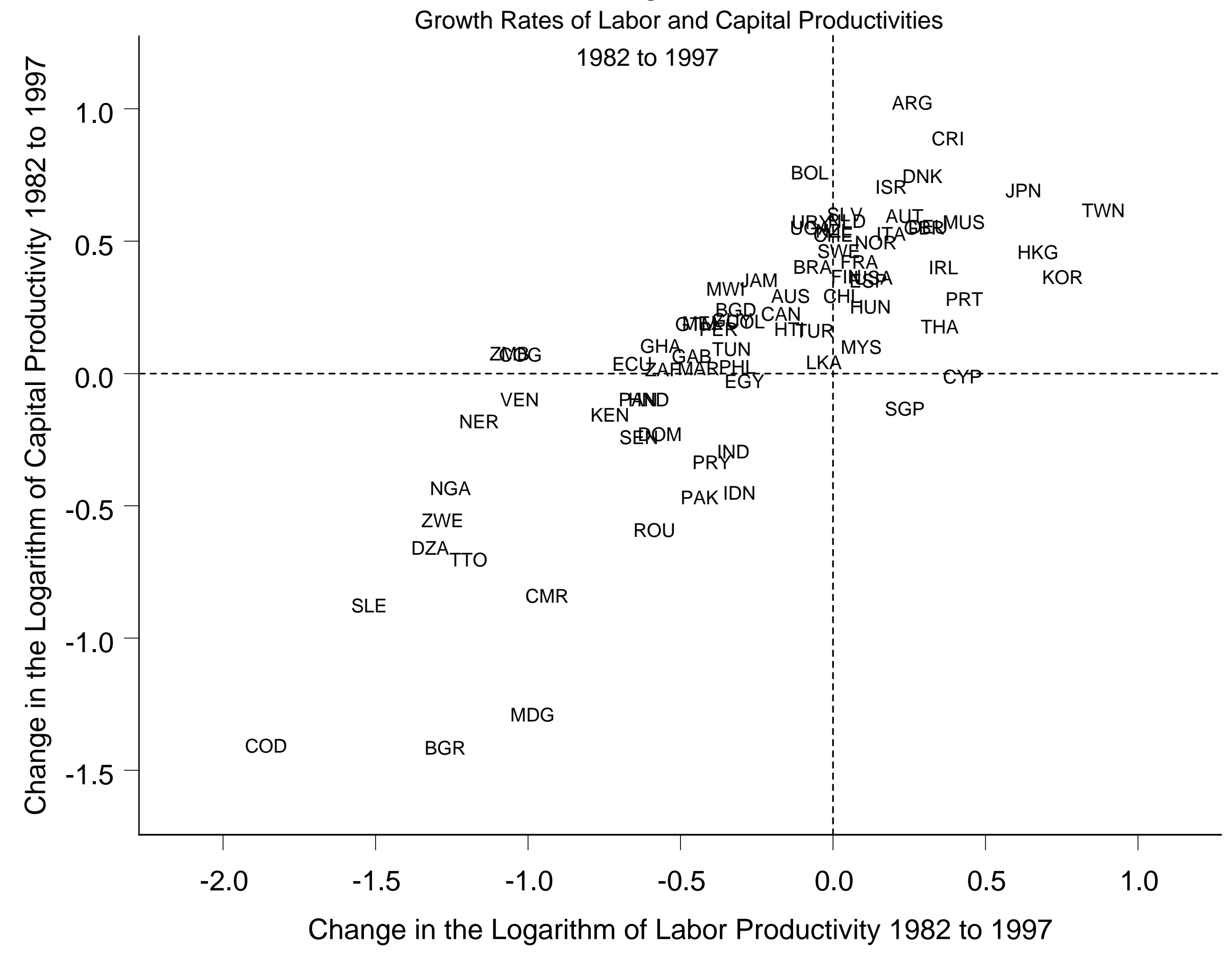


Figure 5

Gross Black Market Premium

1995 and 1980

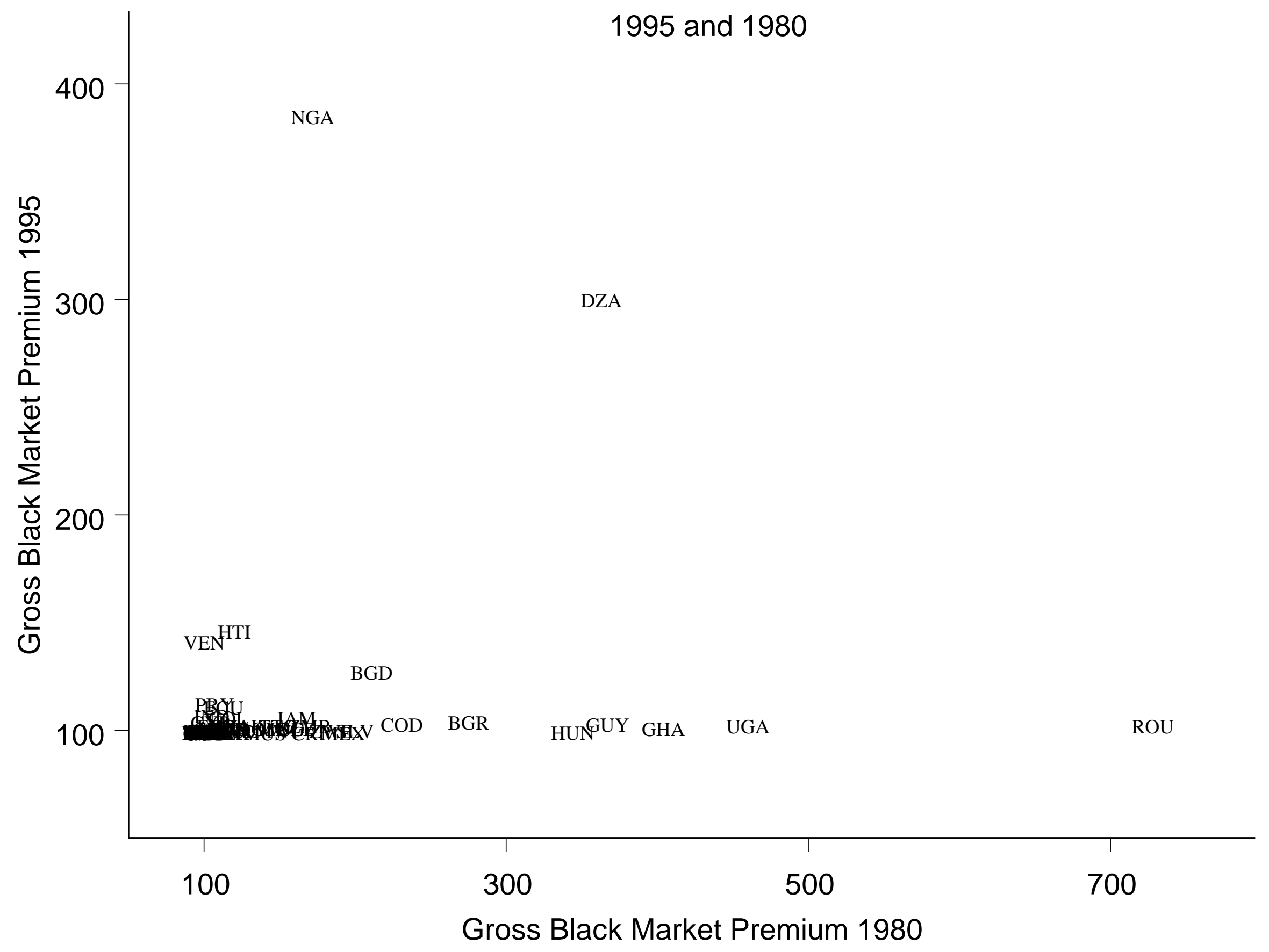


Figure 6

Distribution of Black Market Premia

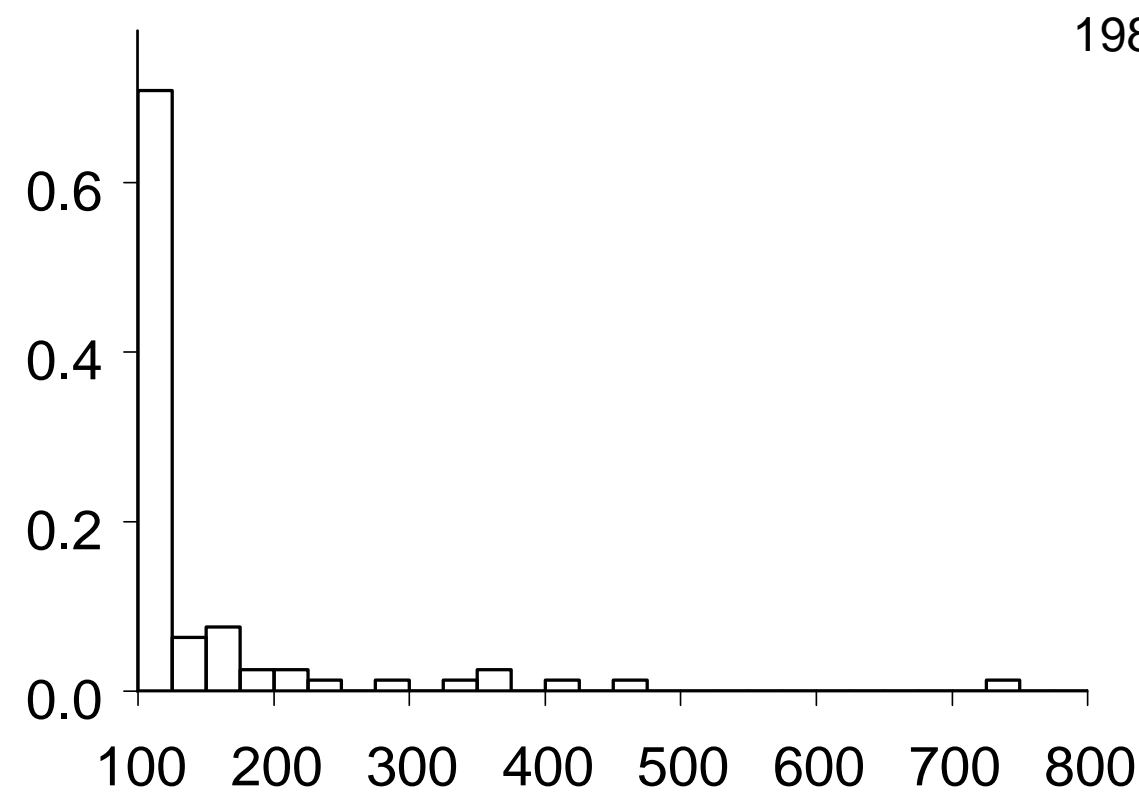

1980, 1985, 1990 and 1995
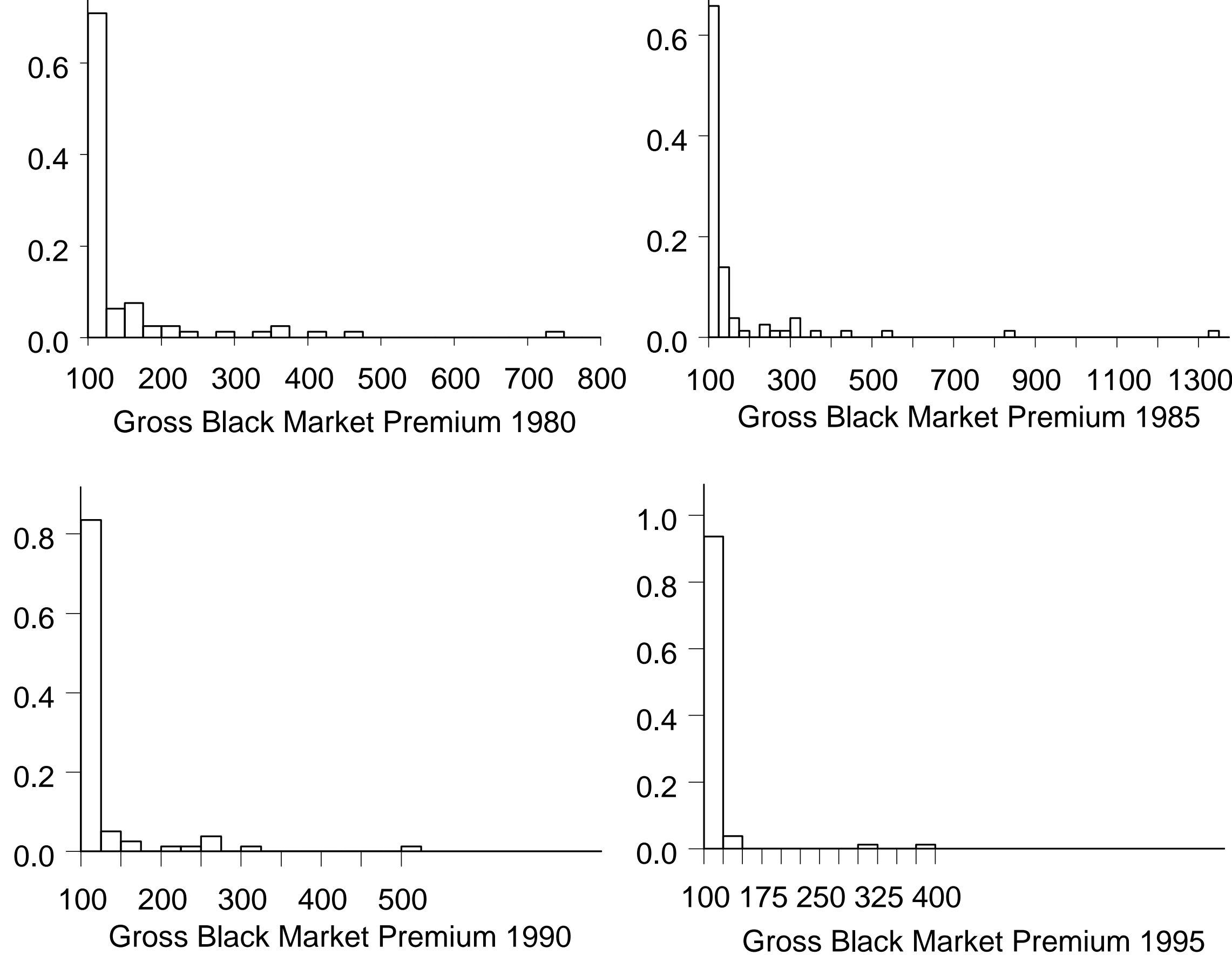

Gross Black Market Premium 1995 


\section{Figure 7}

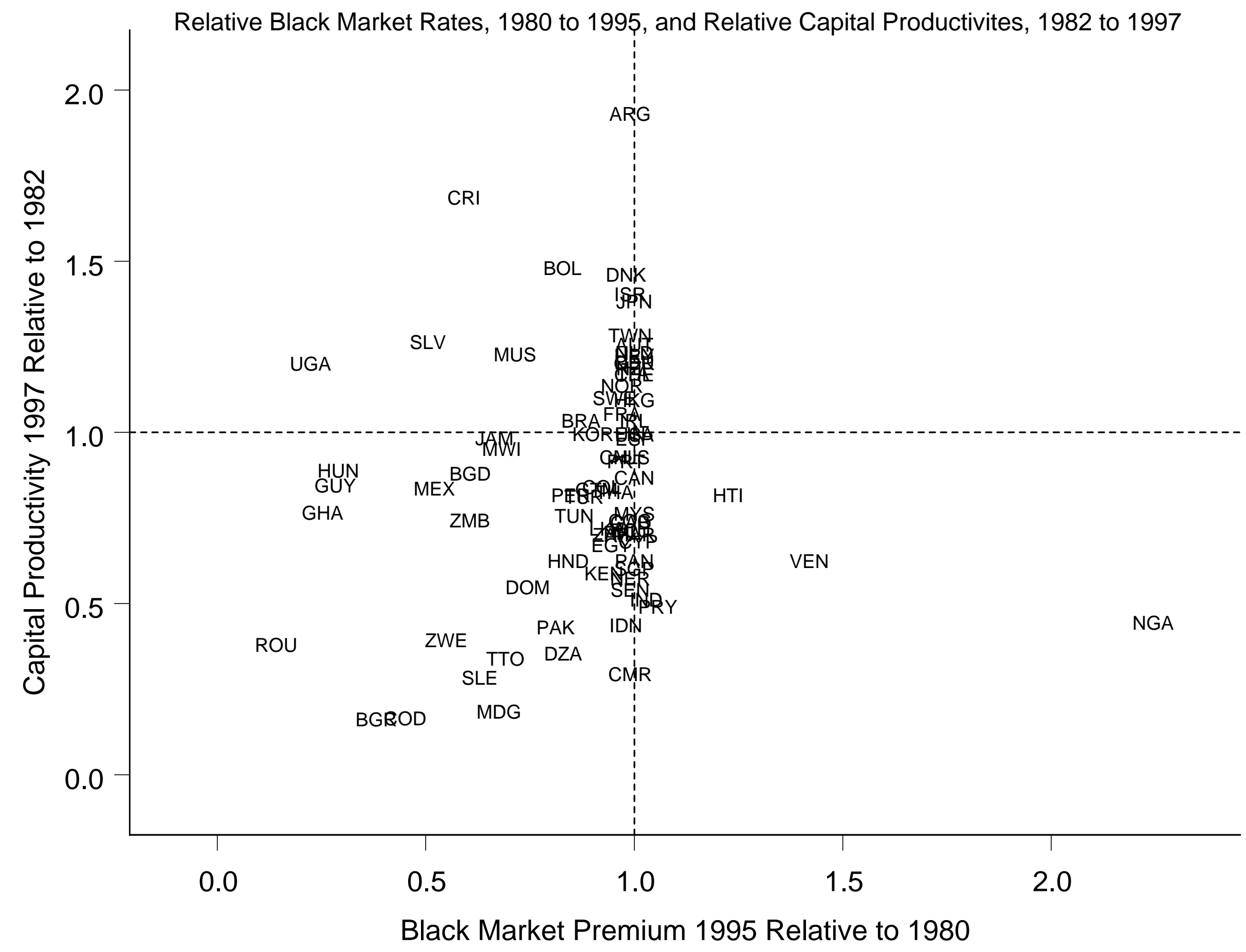


Figure 8

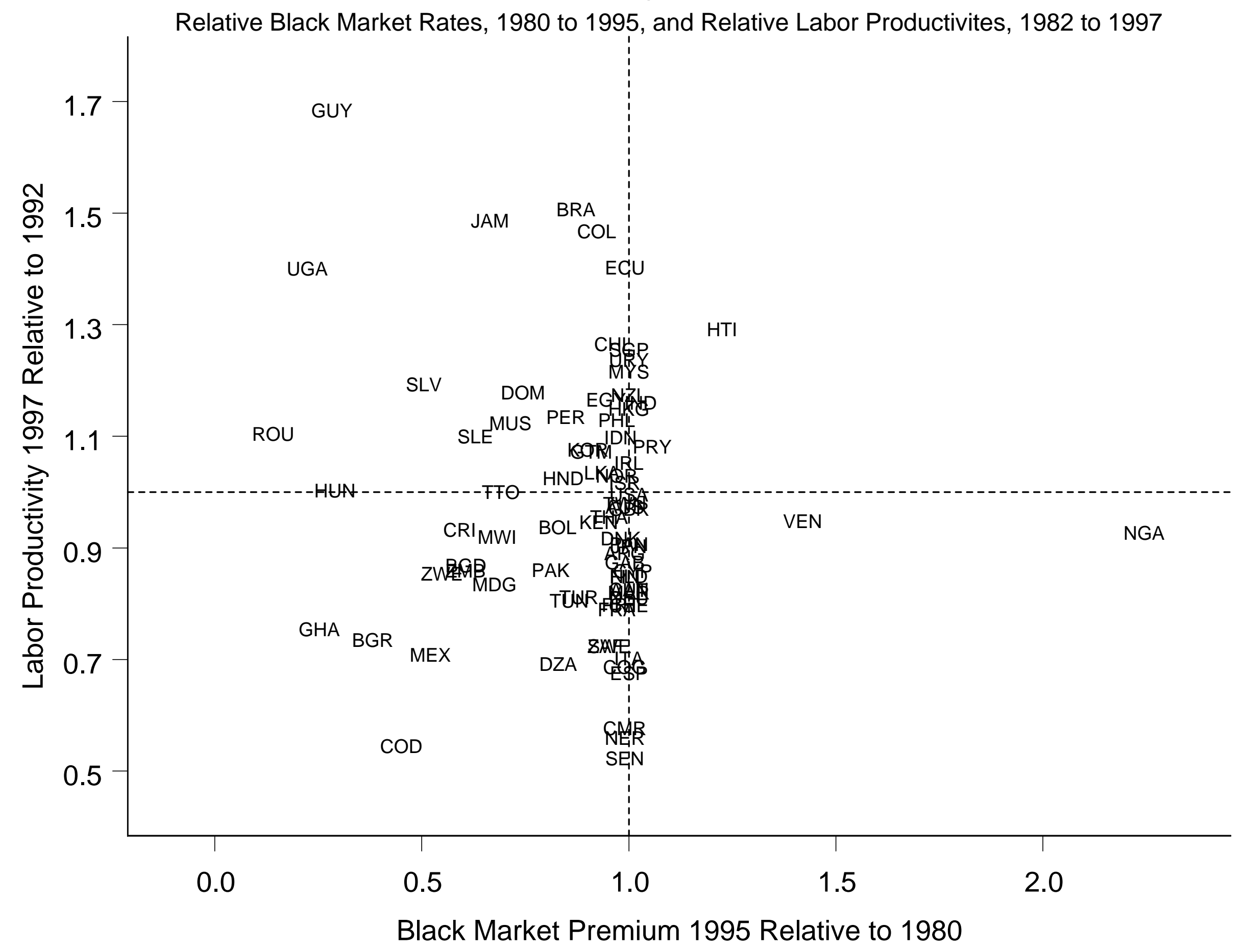




\section{Figure 9}

Relative Black Market Rates and Relative Capital Productivities By Five-year Periods
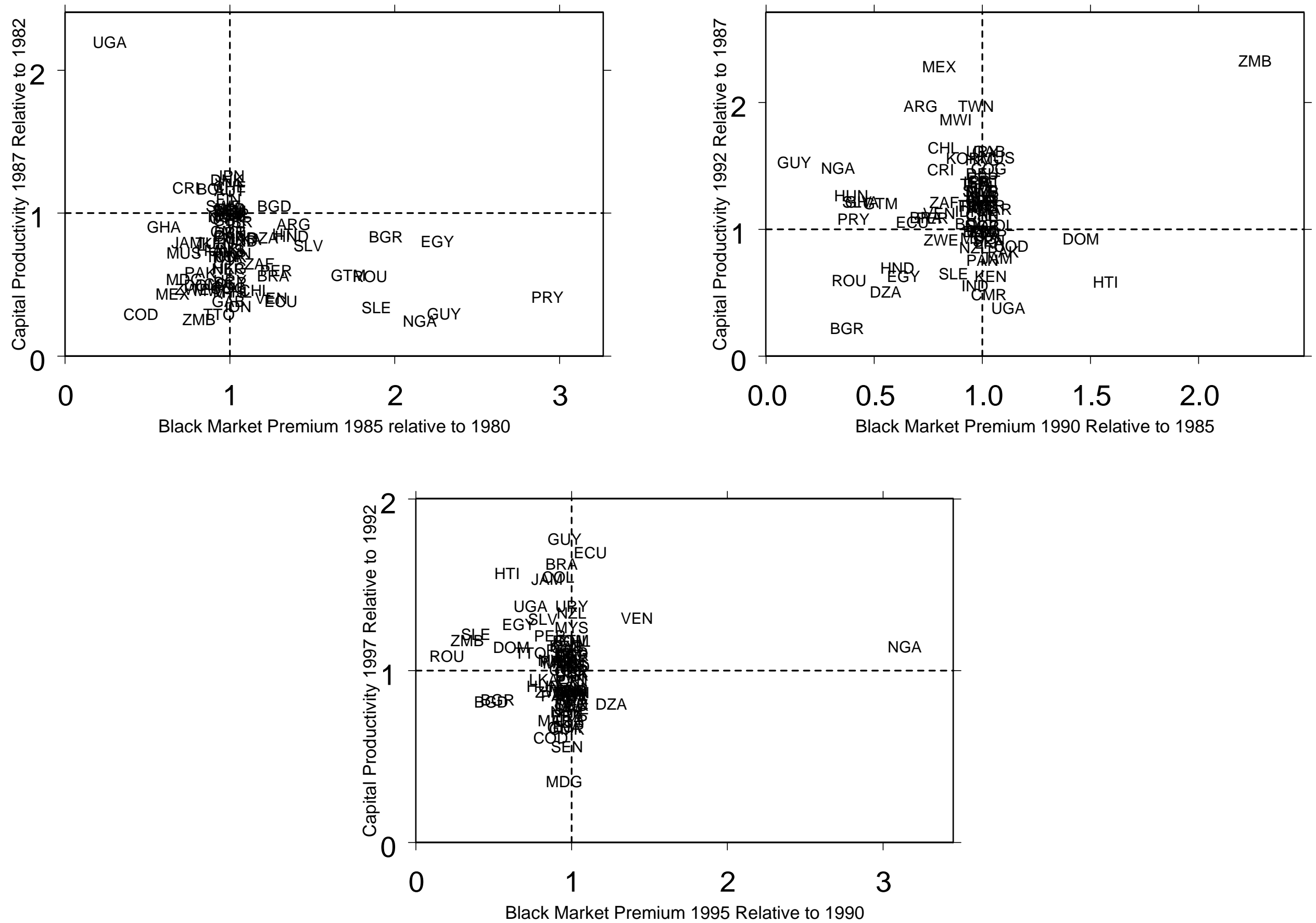
Figure 10

Relative Black Market Rates and Relative Labor Productivities

By Five-year Periods
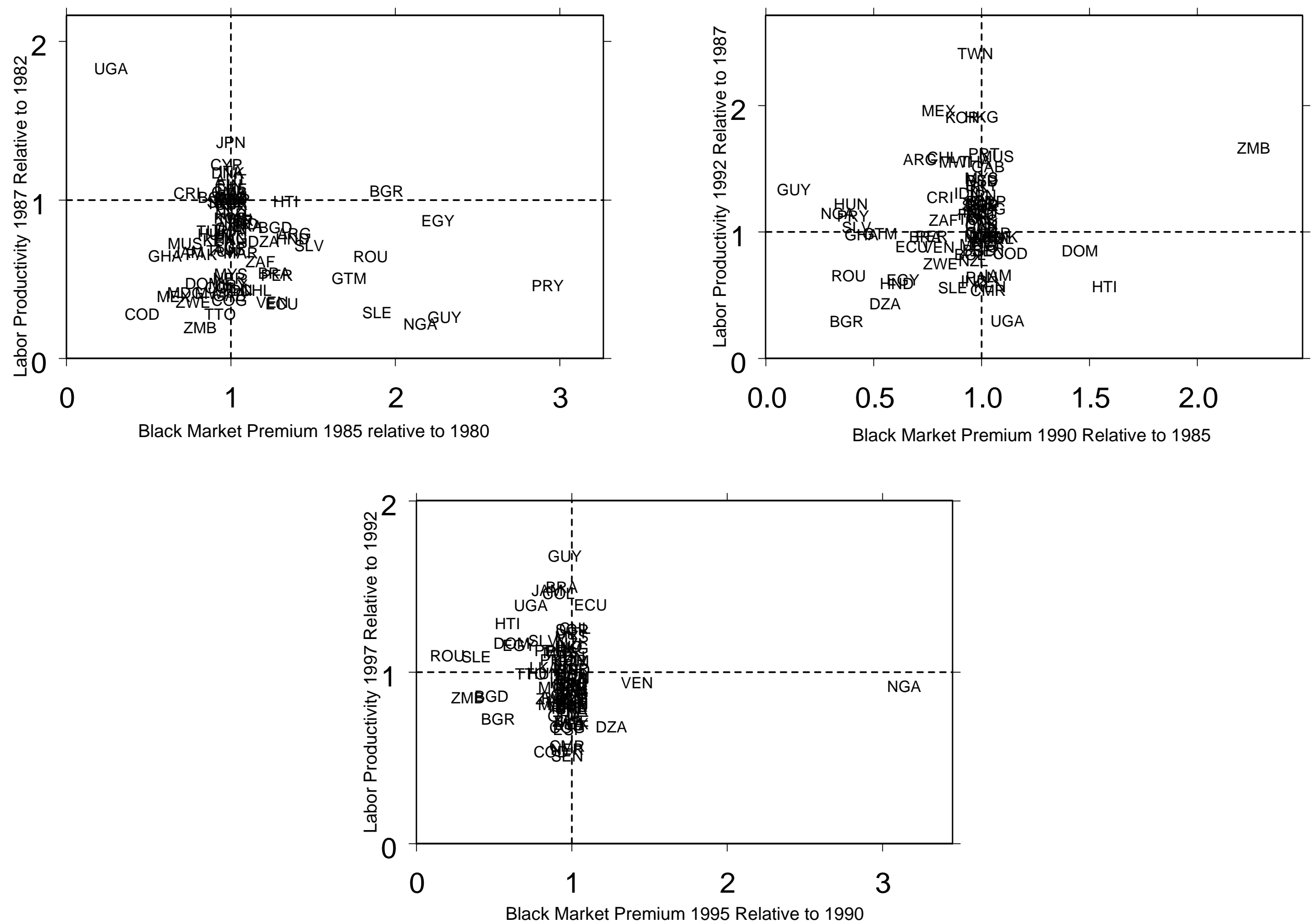